\title{
Flow of endogenous and exogenous nitrogen in different segments of the small intestine in pigs fed diets with soyabean concentrate, soyabean meal or rapeseed cake
}

\author{
W. Grala ${ }^{1,2,5}$, Lucyna Buraczewska ${ }^{1,4}$, Justyna Wasilewko', \\ M.W.A. Verstegen ${ }^{2}$, S. Tamminga ${ }^{2}$, A.J.M. Jansman ${ }^{3}$, J. Huisman ${ }^{3}$ \\ and W. Korczyński ${ }^{1}$
}

'The Kielanowski Institute of Animal Physiology and Nutrition,

Polish Academy of Sciences

05-110 Jabtonna, Poland

${ }^{2}$ Wageningen Institute of Animal Sciences (WIAS), Animal Nutrition Group,

Wageningen Agricultural University

PO Box 338, 6700 AH Wageningen. The Netherlands

${ }^{3}$ TNO-Nutrition and Food Research Institute,

Department of Animal Nutrition and Physiology (ILOB)

PO Box 15, 6700 AA Wageningen, The Netherlands

(Received 1 October 1997; accepted 14 January 1998)

\section{ABSTRACT}

Six barrows of an average initial BW $27.5 \pm 1.2 \mathrm{~kg}$ were used. Each pig was fitted with two cannulas in different segments of the small intestine: pig 1 in the duodenum $(\mathrm{Cl})$ and upper jejunum (C2), pig 2 in $\mathrm{C} 2$ and the lower jejunum (C3), pig 3 in $\mathrm{C} 2$ and $\mathrm{C} 3$, pig 4 in $\mathrm{Cl}$ and the terminal ileum (C4), pig 5 in $\mathrm{C} 3$ and $\mathrm{C} 4$, pig 6 in $\mathrm{C} 1$ and $\mathrm{C} 4$. Pigs were also fitted with one catheter in the vena jugularis for blood sampling and with a second one in the arteria carotis for continuous infusion of ${ }^{15} \mathrm{~N}$-leucine $\left(4.2 \mathrm{mg} / \mathrm{kg}^{0.75} \mathrm{BW} / \mathrm{d}\right)$. Pigs were used in a crossover design experiment with three treatments and three periods of digesta collection $(36 \mathrm{~h})$ and blood sampling $(36 \mathrm{~h})$. Maize starch-based diets that contained: soyabean concentrate (SC), a mixture of toasted and untoasted soyabean meal (mSBM) of a high trypsin inhibitor activity, or rapeseed cake (RC) of a high NDF

\footnotetext{
${ }^{4}$ Corresponding author

${ }^{5}$ Present address: BASF Polska Sp. z o.o., Aleje Jerozolimskie 154, 02-325 Warszwa, Poland
} 
content were used in the experiment. The flow of endogenous and exogenous $\mathrm{N}$ along the small intestine and the net reabsorption rate of endogenous $\mathrm{N}$ were estimated.

In the $\mathrm{Cl}$ digesta of pigs fed on the $\mathrm{SC}, \mathrm{mSBM}$ and $\mathrm{RC}$ diets, total $\mathrm{N}$ was 138,127 and $126 \%$ of the ingested $\mathrm{N}$, respectively. Sixteen, 15 and $10 \%$ of the ingested $\mathrm{N}$ was absorbed up to $\mathrm{Cl}$, and 11.1. 11.6 and $9.4 \mathrm{~g}$ of endogenous $\mathrm{N}(\mathrm{Ed}-\mathrm{N})$ per $\mathrm{kg}$ DM intake was secreted, respectively. For corresponding diets in the $\mathrm{C} 2$ digesta, total $\mathrm{N}$ was 126,117 and $111 \%$ of the ingested $\mathrm{N}$. Thirty four, 11 and $31 \%$ of the exogenous $\mathrm{N}(\mathrm{Ex}-\mathrm{N})$ inflow and $-32,1$ and $-39 \%$ of the Ed-N inflow was absorbed. In the $\mathrm{C} 3$ digesta, total $\mathrm{N}$ was 44,47 and $43 \%$ of the ingested $\mathrm{N}$, while 81,71 and $71 \%$ of the Ex-N inflow and 54,38 and $49 \%$ of the Ed-N inflow was absorbed, respectively. Accordingly, in the C4 digesta total $\mathrm{N}$ was 24,33 and $33 \%$ of the ingested $\mathrm{N}$, and 45,43 and $4 \%$ of the Ex-N inflow was absorbed. True $\mathrm{N}$ digestibility at the terminal ileum was 94,88 and $82 \%$ for the SC. $\mathrm{mSBM}$ and $\mathrm{RC}$ diets. The reabsorption rate of endogenous $\mathrm{N}$ before the terminal ileum was estimated as 75,51 and $69 \%$, respectively.

It was concluded that regardless of the dietary protein source, the middle segment of the small intestine is the site of the most intense absorption of endogenous and exogenous $\mathrm{N}$. Reabsorption rather than secretion of endogenous nitrogen along the pig's small intestine seems to be influenced by dietary factors.

KEY WORDS: pigs, endogenous nitrogen, secretion, absorption, flow

\section{INTRODUCTION}

Secretion and absorption of nitrogenous compounds occur simultaneously along the intestinal tract in the pig. These two processes are influenced by a number of factors such as age and body weight of animals, protease inhibitors and dietary fibres. Dietary antinutritional factors (ANF) may increase endogenous $\mathrm{N}$ losses at the terminal ileum and decrease digestibility of dietary protein (Nyachoti et al., 1997). The energy and protein requirements for maintenance may be increased as a result of extra synthesis of endogenous protein to replenish the losses (De Lange et al., 1995) and, therefore, less dietary $\mathrm{N}$ can be used for retention (Grala et al., 1998). In that respect, the extent of recycling of endogenous protein [secretion, reabsorption and (re)synthesis] may have a significant impact on the post-absorptive efficiency of amino acid utilization for protein deposition (Nyachoti et al., 1997).

Huisman et al. (1993) calculated that about $30 \%$ of urinary $\mathrm{N}$ may originate from $\mathrm{N}$ losses, which occur during recycling of endogenous protein. The calculation is based on the $75 \%$ reabsorbtion of endogenous $\mathrm{N}$ before the terminal ileum (Souffrant, 1991). In terms of effective pig production it is important to know whether different losses of endogenous $\mathrm{N}$ affected by different protein sources are associated with different or similar secretion of endogenous protein and its reabsorption rate up to the terminal ileum.

The objective of this study was to estimate the flow of endogenous and exogenous $\mathrm{N}$ along the small intestine of pigs fed semi-purified diets with soyabean con- 
centrate, a mixture of toasted and untoasted soyabean meal, or rapeseed cake. Another aim of this study was to estimate the net reabsorption rate of endogenous $\mathrm{N}$ in the small intestine when using different protein sources. The trial was run on cannulated pigs using the ${ }^{15} \mathrm{~N}$-isotope dilution technique.

\section{MATERIAL AND METHODS}

\section{Protein sources}

Three protein sources were used in the study: 1 . a commercial soyabean concentrate (SC), 2. a mixture of toasted soyabean meal and untoasted soyabean meal ( $\mathrm{mSBM}$; ratio of $75: 25$, respectively), and 3. toasted rapeseed cake (RC). It was assumed that each protein source affects the flow of endogenous $\mathrm{N}$ along the small intestine in pigs in a different way. The $\mathrm{SC}$ was considered to cause low flow, while $\mathrm{mSMB}$ and $\mathrm{RC}$ a high flow. The RC was prepared by CETIOM-GERDOC (Pessac, France) from a double-low glucosinolate variety of rape oilseeds (Brassica napus L.). A detailed description of the technological processing of the soyabean and rapeseed products has already been presented elsewhere (Grala et al., 1997b). Chemical characteristics of the feedstuffs is given in Table 1.

\section{Animals and housing}

The experiment was carried out using six Polish Landrace barrows. Pigs were 12 to 13 -wk-old with $\mathrm{BW}( \pm \mathrm{SE})$ of $27.5 \mathrm{~kg}( \pm 1.2 \mathrm{~kg})$ upon arrival. They were individually housed in metabolism cages at an ambient room temperature of 22 to $24^{\circ} \mathrm{C}$ and a relative air humidity of $55 \%$. Pigs were fed a commercial diet for the adaptation period. The experimental procedures were approved by the ethics committee of The Kielanowski Institute of Animal Physiology and Nutrition.

\section{Diets and feeding}

The SC, mSBM and RC were the only protein sources in the maize starch-based diets. Diets were balanced for the apparent ileal digestible (ID) crude protein (CP; $\mathrm{N} x$ 6.25) and essential amino acids (AA). The contents of ID essential AA (Lys, Thr, Met + Cys, and Trp) were at least $85 \%$ of pigs' requirements (CVB, 1994). Apparent ileal digestibility of $\mathrm{CP}$ and $\mathrm{AA}$ of the diets containing the same ingredients were determined in a previous ${ }^{15} \mathrm{~N} /$ ileal digestibility experiment (Grala et al., 1997b). In the present study, $\mathrm{Cr}_{2} \mathrm{O}_{3}$ was used as a solid-phase marker $(1.5 \mathrm{~g} / \mathrm{kg}$ feed) and Co-EDTA as a liquid-phase marker ( $5 \mathrm{~g} / \mathrm{kg}$ feed). The diets were pelleted 
TABLE 1

Chemical composition of feeds, g/kg DM

\begin{tabular}{|c|c|c|c|}
\hline & & & \\
\hline & $\mathrm{SC}$ & $\mathrm{mSBM}^{1}$ & $\mathrm{RC}$ \\
\hline Dry matter & 953.0 & 909.0 & 947.0 \\
\hline Crude protein & 709.3 & 555.0 & 356.9 \\
\hline Ether extract & 8.4 & 13.6 & 122.5 \\
\hline Ash & 72.4 & 73.6 & 71.8 \\
\hline Crude fibre & 29.4 & 39.9 & 153.1 \\
\hline NDF & - & 75.7 & 241.8 \\
\hline $\mathrm{TIA}, \mathrm{mg} / \mathrm{g}^{2}$ & 2.5 & 14.5 & - \\
\hline Glucosinolates, $\mu \mathrm{m} / \mathrm{g}^{3}$ & - & - & 12.6 \\
\hline Amino acids & & & \\
\hline arginine & 47.6 & 42.7 & 21.1 \\
\hline histidine & 19.8 & 15.6 & 9.2 \\
\hline isoleucine & 33.2 & 26.9 & 14.9 \\
\hline leucine & 57.9 & 44.5 & 25.8 \\
\hline lysine & 46.5 & 37.9 & 18.6 \\
\hline methionine & 10.3 & 7.7 & 6.4 \\
\hline cystine & 11.1 & 8.8 & 8.1 \\
\hline phenylalanine & 37.1 & 33.3 & 12.1 \\
\hline threonine & 27.3 & 24.8 & 17.3 \\
\hline tryptophan & 9.2 & 7.2 & 4.6 \\
\hline valine & 35.1 & 30.9 & 21.1 \\
\hline alanine & 31.2 & 29.0 & 16.8 \\
\hline aspartic acid & 84.8 & 79.8 & 27.6 \\
\hline glutamic acid & 127.4 & 108.7 & 58.1 \\
\hline glycine & 31.5 & 26.2 & 19.1 \\
\hline proline & 45.3 & 69.4 & 21.8 \\
\hline serine & 35.7 & 31.9 & 18.0 \\
\hline tyrosine & 25.7 & 19.8 & 11.8 \\
\hline
\end{tabular}

I $\mathrm{SC}$ is soyabean concentrate, $\mathrm{mSBM}$ is mixture of toasted soyabean meal and untoasted soyabean meal (ratio of $75: 25$, respectively), and $R C$ is toasted rapeseed cake

2 trypsin inhibitor activity (TIA) expressed as milligrams of trypsin inhibited per gram of the product's DM

3 fat-free DM

in low-temperature conditions $\left(<60^{\circ} \mathrm{C}\right)$. The ingredient content and calculated chemical composition of the diets are given in Tables 2 and 3 , respectively.

During the experimental periods pigs were given equal meals at 8.00 and $20.00 \mathrm{~h}$. A daily amount of feed offered to each pig was at a level 2.7 times its maintenance requirement for metabolizable energy (ME) $\left(2.7 \times 420 \mathrm{~kJ} \mathrm{ME} / \mathrm{kg}^{0.75} ; \mathrm{ARC}, 1981\right)$. Water was available ad libitum from drinking nipples. 
TABLE 2

Composition of the experimental diets, $\%$

\begin{tabular}{|c|c|c|c|}
\hline & \multicolumn{3}{|c|}{ Diet } \\
\hline & $\mathrm{SC}$ & $\mathrm{mSBM}^{\prime}$ & $\mathrm{RC}$ \\
\hline Soya concentrate & 18.17 & - & - \\
\hline $\mathrm{mSBM}^{1}$ & - & 31.50 & - \\
\hline Rapeseed cake & - & - & 46.78 \\
\hline Maize starch & 43.605 & 39.362 & 27.274 \\
\hline Dextrose & 15.00 & 15.00 & 15.00 \\
\hline Soya oil & 4.10 & 2.45 & 4.05 \\
\hline Cellulose & 11.00 & 4.40 & - \\
\hline $\mathrm{CaCO}_{3}$ & 1.16 & 1.20 & 0.75 \\
\hline $\mathrm{Ca}\left(\mathrm{H}_{2} \mathrm{PO}_{4}\right) 2 \mathrm{H}_{2} \mathrm{O}$ & 1.80 & 1.70 & 1.35 \\
\hline $\mathrm{NaCl}^{2}$ & 0.30 & 0.30 & 0.30 \\
\hline $\mathrm{KHCO}_{3}$ & 0.82 & 0.10 & 0.45 \\
\hline $\mathrm{NaHCO}_{3}$ & 0.25 & 0.25 & 0.25 \\
\hline $\mathrm{MgO}$ & 0.06 & - & - \\
\hline $\mathrm{Cr}_{2} \mathrm{O}_{3}$ & 0.15 & 0.15 & 0.15 \\
\hline Co-EDTA & 2.50 & 2.50 & 2.50 \\
\hline L-lysine $\mathrm{HCl}$ & - & - & 0.146 \\
\hline DL-methionine & 0.071 & 0.088 & - \\
\hline L-threonine & 0.014 & - & - \\
\hline Premix ${ }^{2}$ & 1.00 & 1.00 & 1.00 \\
\hline
\end{tabular}

mixture of toasted $(75 \%)$ and untoasted $(25 \%)$ soyabean meal

2 the premix supplied per kilogram of feed: $9,000 \mathrm{IU}$ of vitamin $A_{1} ; 1,800 \mathrm{IU}$ of vitamin $D_{3} ; 40 \mathrm{mg}$ of vitamin E; $5 \mathrm{mg}$ of riboflavin; $30 \mathrm{mg}$ niacin; $12 \mathrm{mg}$ of d-pantothenic acid; $1,000 \mathrm{mg}$ of choline, $40 \mathrm{mg}$ of vitamin $\mathrm{B}_{12} ; 2 \mathrm{mg}$ of thiamine; $3 \mathrm{mg}$ of pyridoxine; $0.1 \mathrm{mg}$ of biotin; $1 \mathrm{mg}$ of folic acid; $3 \mathrm{mg}$ of vitamin $\mathrm{K} ; 50 \mathrm{mg}$ of ascorbic acid; $72.8 \mathrm{mg}$ of $\mathrm{Zn}\left(\mathrm{ZnSO}_{4} \times \mathrm{H}_{2} \mathrm{O}\right) ; 44 \mathrm{mg}$ of $\mathrm{Mn}\left(\mathrm{MnO}_{2}\right)$; $80 \mathrm{mg}$ of $\mathrm{Fe}\left(\mathrm{FeSO}_{4} \times 7 \mathrm{H}_{2} \mathrm{O}\right) ; .525 \mathrm{mg}$ of $\mathrm{Co}\left(\mathrm{CoSO}_{4} \times 5 \mathrm{H}_{2} \mathrm{O}\right) ; 0.38 \mathrm{mg}$ of $\mathrm{K}(\mathrm{KI}) ; 0.254 \mathrm{mg}$ of $\mathrm{Cu}$ $\left(\mathrm{CuSO}_{4} \times 5 \mathrm{H}_{2} \mathrm{O}\right) ; 0.06 \mathrm{mg}$ of $\mathrm{Se}\left(\mathrm{Na}_{2} \mathrm{SeO}_{3} \times 5 \mathrm{H}_{2} \mathrm{O}\right) ; 40 \mathrm{mg}$ tylosin.

TABLE 3

The analyzed ${ }^{\prime}$ and calculated ${ }^{2}$ chemical composition of the experimental diets, $\%$ as-fed basis

\begin{tabular}{|c|c|c|c|}
\hline & \multicolumn{3}{|c|}{ Diet } \\
\hline & $\mathrm{SC}$ & mSBM & $\mathrm{RC}$ \\
\hline Dry matter' & 87.14 & 86.93 & 87.60 \\
\hline Crude protein $(\mathrm{N} \times 6.25)^{\prime}$ & 11.28 & 15.05 & 14.65 \\
\hline Ether extract ${ }^{\prime}$ & 3.35 & 1.79 & 8.11 \\
\hline Crude fibre $^{1}$ & 8.23 & 3.63 & 5.86 \\
\hline $\mathrm{Ash}^{\prime}$ & 4.64 & 4.96 & 5.67 \\
\hline$N^{\prime} F^{\prime}$ & 11.50 & 6.09 & 11.76 \\
\hline $\mathrm{TIA}(\mathrm{mg} / \mathrm{g})^{2}$ & 0.40 & 3.38 & ND \\
\hline $\mathrm{Cr}^{1}$ & 0.142 & 0.142 & 0.142 \\
\hline $\mathrm{Co}^{1}$ & 0.242 & 0.242 & 0.242 \\
\hline ID $\mathrm{CP}^{2}$ & 10.4 & 10.4 & 10.4 \\
\hline $\mathrm{ME}, \mathrm{MJ} / \mathrm{kg}^{2}$ & 14.4 & 14.4 & 14.4 \\
\hline
\end{tabular}




\section{Experimental procedures}

The scheme of the experiment is presented in Table 4 . After 16 days of the adaptation period, each pig was fitted with two cannulas. The cannulas were placed in the small intestine as follows:

cannula 1: in the duodenum (C1); T-shape, silicon cannula ( $\varnothing 10 \mathrm{~mm})$; placed about $35 \mathrm{~cm}$ distal to the pylorus.

cannula 2: upper jejunum (C2); T-shape, silicon cannula ( $\varnothing 10 \mathrm{~mm})$; placed posterior to $\mathrm{C} 1$ at a distance of about $300 \mathrm{~cm}$.

cannula 3: lower jejunum (C3); T-shape, silicon cannula $(\varnothing 20 \mathrm{~mm})$; placed anterior to the end of the ileum at a distance of about $250-300 \mathrm{~cm}$.

cannula 4: at the terminal ileum (C4); PVTC-cannula (van Leeuwen et al., 1991). Each pig was provided with two cannulas as following:

pig 1: $\mathrm{C} 2+\mathrm{C} 3$

pig 2: $\mathrm{C} 1+\mathrm{C} 2$

pig 3: $\mathrm{C} 2+\mathrm{C} 3$

pig 4: $\mathrm{C} 1+\mathrm{C} 4$

pig 5: $\mathrm{C} 3+\mathrm{C} 4$

pig 6: $\mathrm{Cl}+\mathrm{C} 4$

After 13 days of a recovery, pigs were catheterized with one catheter in the vena jugularis for blood sampling and the second one in the arteria carotis for infusion of the ${ }^{15} \mathrm{~N}$-leucine $\left(99 \%{ }^{15} \mathrm{~N}\right.$-enrichment; Euriso-Top, Belgium). The commercial diet was replaced by the experimental diets and a 34-day continuous ${ }^{15} \mathrm{~N}$-leucine infusion started. The daily rate of the ${ }^{15} \mathrm{~N}$-leucine infusion was about $4.2 \mathrm{mg}$ per $\mathrm{kg}$ BW per day. ${ }^{15} \mathrm{~N}$-leucine dissolved in a sterile non-pyrogenic, physiological saline solution $(\mathrm{NaCl}, 9 \mathrm{~g} / \mathrm{L})$ was infused at a rate of about $45 \mathrm{~mL} / \mathrm{d}$ using perfusion pumps (Fr. B. Braun Melsungen AG, Germany).

Pigs were used in a crossover design experiment comprising three dietary treatments and three periods. Such a design allowed obtaining three observations for each cannula on each treatment. Diets with SC, RC and mSBM were fed as follows:

$\begin{array}{llll} & \text { Period 1 } & \text { Period 2 } & \text { Period 3 } \\ \text { pig 1 }(\mathrm{C} 2+\mathrm{C} 3): & \text { SC } & \text { RC } & \text { mSBM } \\ \text { pig 2 }(\mathrm{C} 1+\mathrm{C} 2): & \text { SC } & \text { RC } & \text { mSBM } \\ \text { pig 3 }(\mathrm{C} 2+\mathrm{C} 3): & \text { mSBM } & \text { SC } & \text { RC } \\ \text { pig 4 }(\mathrm{C} 1+\mathrm{C} 4): & \text { mSBM } & \text { SC } & \text { RC } \\ \text { pig 5 }(\mathrm{C} 3+\mathrm{C} 4): & \text { RC } & \text { mSBM } & \text { SC } \\ \text { pig 6 }(\mathrm{C} 1+\mathrm{C} 4): & \mathrm{RC} & \text { mSBM } & \text { SC }\end{array}$

Digesta collection lasted $72 \mathrm{~h}$. An 8-day adaptation period to the experimental diets preceded each digesta collections. The first period (P1) was started after 9 
GRALA W. ET AL.

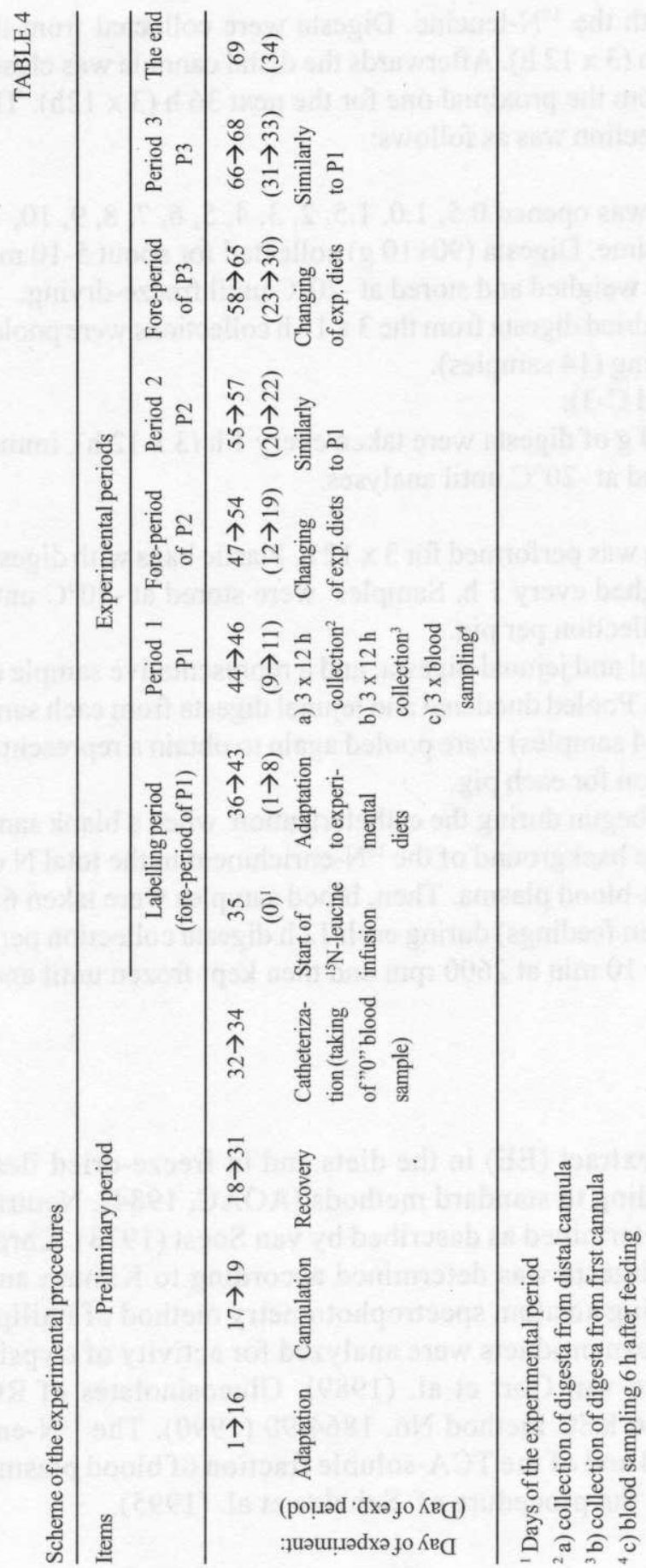


days of labelling the pigs with the ${ }^{15} \mathrm{~N}$-leucine. Digesta were collected from the distal cannula for the first $36 \mathrm{~h}(3 \times 12 \mathrm{~h})$. Afterwards the distal cannula was closed and digesta were collected from the proximal one for the next $36 \mathrm{~h}(3 \times 12 \mathrm{~h})$. The procedure for the digesta collection was as follows:

A. Duodenal digesta ( $\mathrm{Cl}$ ):

The duodenal cannula was opened $0.5,1.0,1.5,2,3,4,5,6,7,8,9,10,11$ and $12 \mathrm{~h}$ after feeding time. Digesta $(90 \pm 10 \mathrm{~g})$ collected for about $5-10 \mathrm{~min}$ at each time point were weighed and stored at $-20^{\circ} \mathrm{C}$ until freeze-drying.

Within a period, freeze-dried digesta from the $3 \times 12 \mathrm{~h}$ collections were pooled per pig and time sampling (14 samples).

B. Jejunal digesta ( $\mathrm{C}-2$ and $\mathrm{C}-3$ ):

Spot samples of $80-100 \mathrm{~g}$ of digesta were taken every $1 \mathrm{~h}(3 \times 12 \mathrm{~h})$, immediately frozen and stored at $-20^{\circ} \mathrm{C}$ until analyses.

C. Ileal digesta (C-4):

A continuous collection was performed for $3 \times 12 \mathrm{~h}$. Plastic bags with digesta were emptied and weighed every $1 \mathrm{~h}$. Samples were stored at $-20^{\circ} \mathrm{C}$ until pooling per $3 \times 12 \mathrm{~h}$ collection per pig.

Pooled samples of duodenal and jejunal digesta, and a representative sample of ileal digesta were freeze-dried. Pooled duodenal and jejunal digesta from each sampling time per pig over $36 \mathrm{~h}$ ( 14 samples) were pooled again to obtain a representative sample from $12 \mathrm{~h}$ collection for each pig.

Blood sampling $(2 \times 4 \mathrm{ml})$ begun during the catheterization when a blank sample was taken to determine the background of the ${ }^{15} \mathrm{~N}$-enrichment in the total $\mathrm{N}$ of the trichloroacetic acid (TCA)-blood plasma. Then, blood samples were taken $6 \mathrm{~h}$ after feeding (midpoint between feedings) during each $12 \mathrm{~h}$ digesta collection period. Blood was centrifuged for $10 \mathrm{~min}$ at $2600 \mathrm{rpm}$ and then kept frozen until analysis of ${ }^{15} \mathrm{~N}$-enrichment.

\section{Chemical analyses}

Nitrogen, DM and ether extract (EE) in the diets and in freeze-dried ileal digesta were analyzed according to standard methods (AOAC, 1984). Neutral detergent fibre (NDF) was determined as described by van Soest (1973). Chromium in the diets and ileal digesta was determined according to Kimura and Miller (1957), and cobalt, using an atom spectrophotometry method of Philips Scientific (1988). The soyabean products were analyzed for activity of trypsin inhibitors (TIA) according to van Oort et al. (1989). Glucosinolates of RC were determined according to EEC method No. $1864 / 90$ (1990). The ${ }^{15} \mathrm{~N}$-enrichment of ileal digesta, feed and of the TCA-soluble fraction of blood plasma was determined according to the procedure of Schulze et al. (1995). 


\section{Calculations and data analyses}

The ratio of ${ }^{15} \mathrm{~N}$-enrichment excess in digesta to that in the TCA-soluble blood plasma, referred to as the dilution factor, was calculated for each site of digesta collection according to the following equation:

$$
\mathrm{DF}=\left({ }^{15} \mathrm{~N}_{\mathrm{dig}}-{ }^{15} \mathrm{~N}_{\mathrm{d}(0)}\right) /\left({ }^{15} \mathrm{~N}_{\mathrm{pl}}-{ }^{15} \mathrm{~N}_{\mathrm{pl}(0)}\right) \times 100
$$

where DF is dilution factor (\%), ${ }^{15} \mathrm{~N}_{\mathrm{dig}}$ is ${ }^{15} \mathrm{~N}$-enrichment of digesta (at. \%), ${ }^{15} \mathrm{~N}_{\mathrm{d}(0)}$ is the background ${ }^{15} \mathrm{~N}$-enrichment in the diet (at. \%), ${ }^{15} \mathrm{~N}_{\mathrm{pl}}$ is ${ }^{15} \mathrm{~N}$-enrichment in the TCA-soluble blood plasma (at. \%), ${ }^{15} \mathrm{~N}_{\mathrm{pt}(0)}$ is the background ${ }^{15} \mathrm{~N}$-enrichment in the TCA-soluble blood plasma (at. \%).

In digesta for the consecutive cannulas, the amount of total $\mathrm{N}[\mathrm{g} / 100 \mathrm{~g} \mathrm{~N}$ intake (NI)] was calculated using $\mathrm{Cr}$ and $\mathrm{Co}$ as indigestible markers according to the following equation:

$$
\mathrm{N}_{\mathrm{tfl}}=\left(\mathrm{N}_{\mathrm{dig}} / \mathrm{N}_{\mathrm{d}}\right) \times\left(\mathrm{M}_{\mathrm{d}} / \mathrm{M}_{\mathrm{dig}}\right) \times 100
$$

where $\mathrm{N}_{\text {tff }}$ is the amount or flow of $\mathrm{N}$ in particular parts of the intestine, $\mathrm{N}_{\mathrm{dig}}$ is the $\mathrm{N}$ content in digesta $(\%), \mathrm{N}_{\mathrm{d}}$ is the $\mathrm{N}$ content of the diet $(\%), \mathrm{M}_{\mathrm{d}}$ and $\mathrm{M}_{\text {dig }}$ are the contents $(\%)$ of indigestible markers in diet and digesta, respectively. The $\mathrm{N}$ flows were separately calculated for each marker.

The endogenous $\mathrm{N}(\mathrm{g} / 100 \mathrm{~g} \mathrm{NI})$ was estimated from the dilution factor (Equation 1) and the total $\mathrm{N}$ (Equation 2):

$$
\mathrm{N}_{\mathrm{efl}}=\mathrm{DF} \times \mathrm{N}_{\mathrm{tfl}} / 100
$$

where $\mathrm{N}_{\mathrm{eff}}$ is the amount of endogenous $\mathrm{N}$ in digesta from different cannulas ( $\mathrm{g} /$ $100 \mathrm{~g} \mathrm{NI}$ ). The amount of exogenous (dietary) $\mathrm{N}$ in digesta was calculated as the difference between the $\mathrm{N}_{\mathrm{tf}}$ and $\mathrm{N}_{\mathrm{et1}}$.

For the estimation of the $\mathrm{N}$ flow ( $\mathrm{g} / \mathrm{kg}$ dry matter intake-DMI) in consecutive segments of the small intestine, the amounts of $\mathrm{N}$ per $100 \mathrm{~g} \mathrm{NI}$ were related to $1000 \mathrm{~g}$ of DMI.

The net absorption of endogenous $\mathrm{N}$, and absorption of exogenous $\mathrm{N}$ in each intestinal segment $(\mathrm{g} / \mathrm{kg}$ DMI) were calculated according to the following scheme: a. $\mathrm{NI}$ minus $\mathrm{N}$ in $\mathrm{C} 1$ digesta, $\mathrm{b} . \mathrm{N}$ in $\mathrm{C} 1$ digesta minus $\mathrm{N}$ in $\mathrm{C} 2$ digesta, $\mathrm{c} . \mathrm{N}$ in $\mathrm{C} 2$ digesta minus $\mathrm{N}$ in $\mathrm{C} 3$ digesta, $\mathrm{d}$. $\mathrm{N}$ in $\mathrm{C} 3$ digesta minus $\mathrm{N}$ in $\mathrm{C} 4$ digesta. The net absorption of total $\mathrm{N}$ in the whole upper intestinal tract was also calculated [(total $\mathrm{N}$ in $\mathrm{Cl}-$ total $\mathrm{N}$ in $\mathrm{C} 4$ digesta) / total $\mathrm{N}$ in $\mathrm{C} 1 \times 100$ ]. Additionally, the net absorption of endogenous $\mathrm{N}$ (reabsorption rate) in the small intestine was calculated $[(\mathrm{N}$ in $\mathrm{C} 1-\mathrm{N}$ in $\mathrm{C} 4) / \mathrm{N}$ in $\mathrm{Cl} \times 100]$ for each treatment. 
Apparent ileal $\mathrm{N}$ digestibility was calculated according to the formula: $\mathrm{NI}-\mathrm{N}$ in $\mathrm{C} 4 / \mathrm{NI} \times 100$.

Part of the scheduled observations could not be included into the data set because of dysfunction of cannulas and/or feed refusals. As a consequence, the number of observations (n) obtained for each cannula and treatment were for the SC diet: $\mathrm{C} 1=3, \mathrm{C} 2=2, \mathrm{C} 3=2, \mathrm{C} 4=3$; for the $\mathrm{mSBM}$ diet: $\mathrm{C} 1=2, \mathrm{C} 2=1, \mathrm{C} 3=1, \mathrm{C} 4=3$; for the RC diet: $\mathrm{C} 1=2, \mathrm{C} 2=1, \mathrm{C} 3=1, \mathrm{C} 4=3$.

\section{RESULTS}

The flow of both markers (ratio $\mathrm{Cr}$ to $\mathrm{Co}$ ) appeared to be in a constant ratio throughout the different intestinal segments (Figure 1). It was assumed, therefore, that the flow of both solid and liquid phase was constant throughout the upper intestinal tract. The results presented in this section were calculated on the average data for both markers within each treatment.

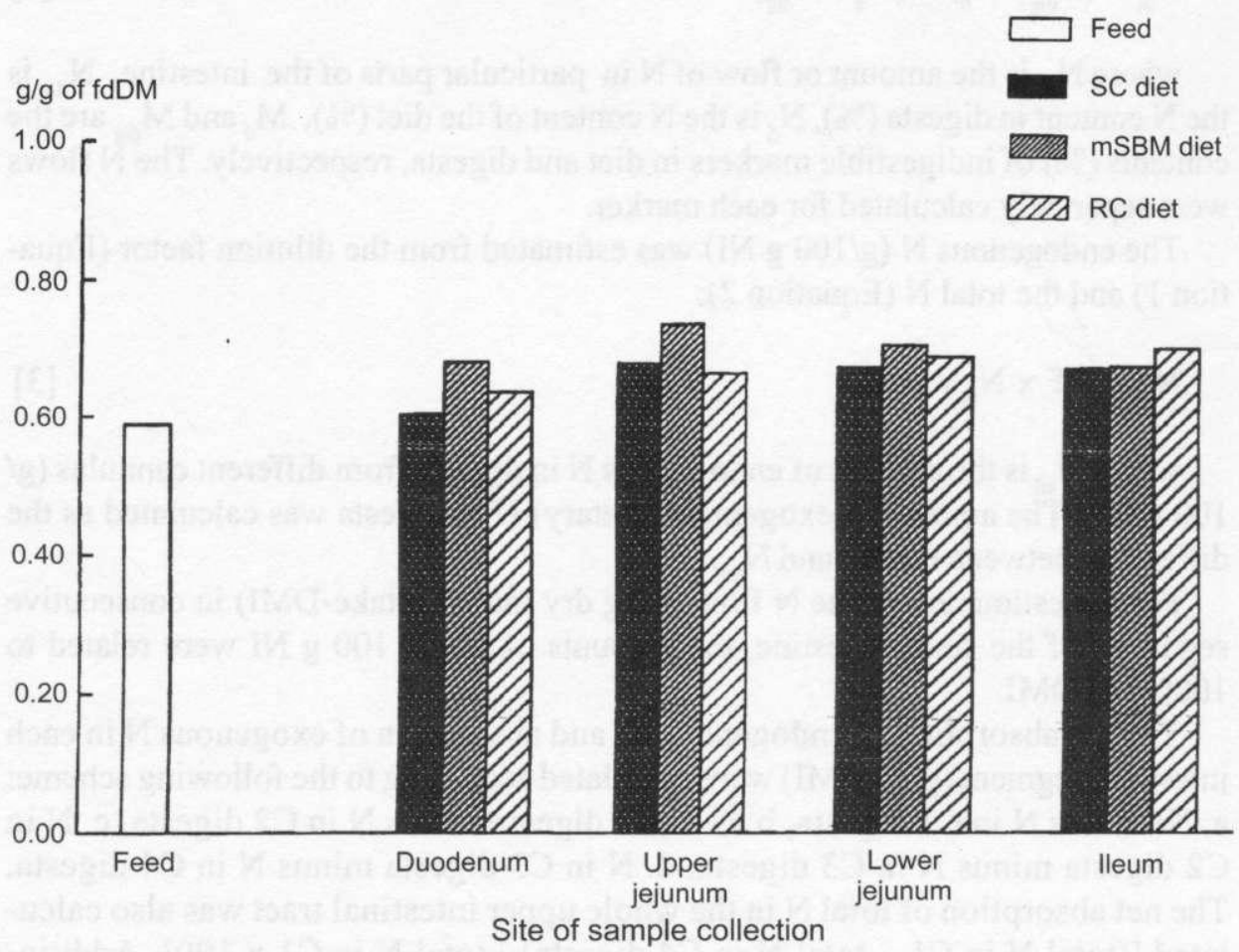

Figure 1. Chromium to cobalt ratios in different segments of the small intestine in pigs fed diets with soyabean concentrate (SC), a mixture of toasted and untoasted soyabean meal (mSBM) or rapeseed cake $(\mathrm{RC})$ 


\section{${ }^{15} \mathrm{~N}$-enrichment of blood plasma and digesta}

The background ${ }^{15} \mathrm{~N}$-enrichment of the $\mathrm{N}$ in the TCA-soluble blood plasma and the diets was 0.3651 and 0.3647 , respectively. The mean ${ }^{15} \mathrm{~N}$-enrichment excesses of the $\mathrm{N}$ in blood plasma ranged from $0.0379( \pm 0.0093)$ at $\%$ for $\mathrm{C} 4$ to 0.0389 $( \pm 0.082)$ at $\%$ for $\mathrm{C} 3$ (Table 5). The highest ${ }^{15} \mathrm{~N}$-enrichment excess of the $\mathrm{N}$ in digesta was found for the $\mathrm{SC}$ and $\mathrm{RC}$ diets in $\mathrm{C} 3$ while for the $\mathrm{mSBM}$ diet, the highest ${ }^{15} \mathrm{~N}$-enrichment excess was in $\mathrm{N}$ of digesta from $\mathrm{C} 4$.

The highest proportion of endogenous $\mathrm{N}$ to total $\mathrm{N}$ was estimated in digesta from $\mathrm{C} 3$ of pigs fed the SC and $\mathrm{RC}$ diet while those fed the mSBM diet had the highest proportion of endogenous $\mathrm{N}$ to total $\mathrm{N}$ in $\mathrm{C} 4$. The lowest dilution factor for each diet was found in duodenal digesta ( $\mathrm{C} 1)$.

TABLE 5

${ }^{15} \mathrm{~N}$-enrichment excess (at. $\left.\%\right)^{1.2}$ in the trichloroacetic acid-soluble blood plasma and in digesta collected from different segments of the small intestine in pigs fed diets with soyabean concentrate (SC), a mixture of toasted and untoasted soyabean meal (mSBM) or rapeseed cake (RC)

\begin{tabular}{|c|c|c|c|}
\hline \multirow[b]{2}{*}{ Item } & \multicolumn{3}{|c|}{ Diet } \\
\hline & $\mathrm{SC}$ & mSBM & $\mathrm{RC}$ \\
\hline Duodenum & {$[n=3]$} & {$[n=2]$} & {$[n=2]$} \\
\hline Blood plasma ${ }^{3}$ & & $0.0389 \pm 0.0082$ & \\
\hline Digesta & $0.0152 \pm 0.0013$ & $0.0129 \pm 0.0018$ & $0.0109 \pm 0.0026$ \\
\hline Dilution factor ${ }^{4}, \%$ & $39.0 \pm 0.4$ & $33.1 \pm 3.1$ & $27.9 \pm 1.8$ \\
\hline Upper jejunum & {$[n=2]$} & {$[n=1]$} & {$[n=1]$} \\
\hline Blood plasma & & $0.0381 \pm 0.0043$ & \\
\hline Digesta & $0.0215 \pm 0.0006$ & 0.0135 & 0.0168 \\
\hline Dilution factor, $\%$ & $56.3 \pm 1.4$ & 35.4 & 43.9 \\
\hline Lower jejunum & {$[n=2]$} & {$[n=1]$} & {$[n=1]$} \\
\hline Blood plasma & & $0.0383 \pm 0.0085$ & \\
\hline Digesta & $0.0289 \pm 0.0043$ & 0.0208 & 0.0221 \\
\hline Dilution factor, $\%$ & $75.5 \pm 0.1$ & 54.3 & 57.7 \\
\hline Terminal ileum & {$[n=3]$} & {$[\mathrm{n}=3]$} & {$[n=3]$} \\
\hline Blood plasma & & $0.0379 \pm 0.0093$ & \\
\hline Digesta & $0.0281 \pm 0.0025$ & $0.0237 \pm 0.0009$ & $0.0173 \pm 0.0029$ \\
\hline Dilution factor, $\%$ & $74.1 \pm 5.8$ & $62.6 \pm 2.8$ & $45.6 \pm 3.3$ \\
\hline
\end{tabular}

1 values represent means $( \pm \mathrm{SD})$ when number observations is $\mathrm{n}>2$

${ }^{2}$ the background ${ }^{15} \mathrm{~N}$-enrichment of the $\mathrm{N}$ in the TCA-soluble blood plasma and feed were $0.365 \mathrm{I}$ and 0.3647 , respectively

${ }^{3}$ mean value for three diets $(\mathrm{n}=7$ for $\mathrm{C} 1 ; \mathrm{n}=4$ for $\mathrm{C} 2 ; \mathrm{n}=5$ for $\mathrm{C} 3$ and $\mathrm{n}=9$ for $\mathrm{C} 4$ )

${ }^{4}$ dilution factor $={ }^{15} \mathrm{~N}$-enrichment excess in digesta $/{ }^{15} \mathrm{~N}$-enrichment excess in blood plasma $x 100$ 


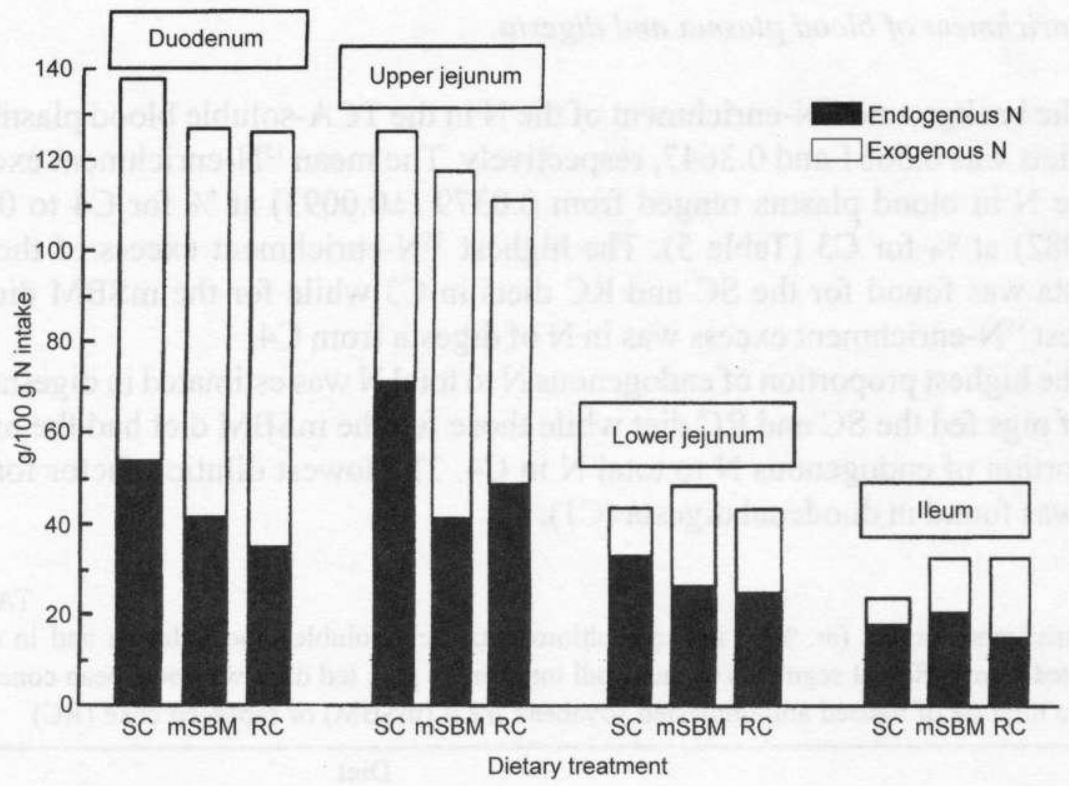

Figure 2. Amounts of total $\mathrm{N}$, endogenous $\mathrm{N}$ and exogenous $\mathrm{N}(\mathrm{g} / 100 \mathrm{~g} \mathrm{~N}$ intake) in different segments of the small intestine in pigs fed diets with soyabean concentrate (SC), a mixture of toasted and untoasted soyabean meal (mSBM) or rapeseed cake (RC)

\section{Nitrogen content in digesta}

The content of total $\mathrm{N}$ in duodenal digesta (C1) was 138,127 and $126 \mathrm{~g} / 100 \mathrm{~g}$ $\mathrm{NI}$, for the SC, mSBM and RC diet, respectively (Figure 2). The endogenous $\mathrm{N}$ content for the $\mathrm{SC}$ and $\mathrm{RC}$ diet was higher in digesta from the upper jejunum (C2) than in digesta from $\mathrm{C} 1$, but similar to that for the mSBM diet. At the same time, the total $\mathrm{N}$ content decreased as compared with the $\mathrm{C} 1$ digesta, because the exogenous $\mathrm{N}$ content of the $\mathrm{C} 2$ digesta was greater by 26,17 and $11 \mathrm{~g} / 100 \mathrm{~g} \mathrm{NI}$, respectively, than the ingested $\mathrm{N}$ amounts.

In the more distal segments of the small intestine the amount of total $\mathrm{N}$ declined progressively with the greatest difference between $\mathrm{C} 3$ and $\mathrm{C} 2$. This difference resulted mainly from a decrease in the exogenous $\mathrm{N}$ contents. The greatest successive decrease in the contents of endogenous and exogenous $\mathrm{N}$ was determined in the digesta of pigs fed the SC diet, while the lowest decrease was found in pigs fed the $\mathrm{mSBM}$ diet. Pigs fed the latter diet had a greater content of endogenous $\mathrm{N}$ of digesta at the terminal ileum (C4) than those fed the SC and RC diets $(21,18$ and $15 \mathrm{~g} / 100$ $\mathrm{g} \mathrm{NI}$ ). It was shown that pigs fed the $\mathrm{SC}$ diet had the lowest exogenous $\mathrm{N}$ content of the $\mathrm{C} 4$ digesta, in comparison with pigs fed the mSBM and $\mathrm{RC}$ diets $(6,12$ and $18 \mathrm{~g} / 100 \mathrm{~g} \mathrm{NI}$, respectively). 


\section{Nitrogen flow in different segments of the small intestine}

Nitrogen flow (g/kg DMI) and absorption rates of $\mathrm{N}(\%)$ in different intestinal segments are presented in Table 6 . In general, the amount of the endogenous $\mathrm{N}$ found in duodenal digesta (C1) was similar for all diets $(9.4-11.6 \mathrm{~g} / \mathrm{kg}$ DMI). Ten to $16 \%$ of the ingested dietary $\mathrm{N}(20.7-27.7 \mathrm{~g} / \mathrm{kg} \mathrm{DMI})$ was already absorbed up to

TABLE 6

Flow of endogenous and exogenous $\mathrm{N}$ and its net absorption $(\mathrm{g} / \mathrm{kg} \mathrm{DMI})^{1}$ in different segments of the small intestine in pigs fed diets with soyabean concentrate (SC), a mixture of toasted and untoasted soyabean meal (mSBM) or rapeseed cake (RC)

\begin{tabular}{|c|c|c|c|c|c|c|c|c|c|}
\hline \multirow{3}{*}{ Item } & \multirow{2}{*}{\multicolumn{3}{|c|}{$\mathrm{SC}$}} & \multicolumn{3}{|c|}{ Diet } & \multirow{2}{*}{\multicolumn{3}{|c|}{$\mathrm{RC}$}} \\
\hline & & & & \multicolumn{3}{|c|}{$\mathrm{mSBM}$} & & & \\
\hline & $\begin{array}{l}\text { endoge- } \\
\text { nous } \mathrm{N}\end{array}$ & $\begin{array}{l}\text { exoge- } \\
\text { nous } \mathrm{N}\end{array}$ & $\begin{array}{c}\text { total } \\
\mathrm{N}\end{array}$ & $\begin{array}{l}\text { endoge- } \\
\text { nous } \mathrm{N}\end{array}$ & $\begin{array}{l}\text { exoge- } \\
\text { nous } \mathrm{N}\end{array}$ & $\begin{array}{c}\text { total } \\
\mathrm{N}\end{array}$ & $\begin{array}{l}\text { endoge- } \\
\text { nous } \mathrm{N}\end{array}$ & $\begin{array}{l}\text { exoge- } \\
\text { nous } \mathrm{N}\end{array}$ & $\begin{array}{c}\text { total } \\
\mathrm{N}\end{array}$ \\
\hline $\mathrm{N}$ intake $(\mathrm{NI})$ & - & 20.7 & - & $x-$ & 27.7 & - & - & 26.8 & - \\
\hline Duodenum & & {$[\mathrm{n}=3]$} & & & {$[\mathrm{n}=2]$} & & & {$[\mathrm{n}=2]$} & \\
\hline $\mathrm{N}$ secretion & 11.1 & - & - & 11.6 & - & - & 9.4 & - & - \\
\hline $\mathrm{N}$ inflow & 11.1 & 20.7 & 31.8 & 11.6 & 27.7 & 39.3 & 9.4 & 26.8 & 36.2 \\
\hline $\mathrm{N}$ outflow & 11.1 & 17.4 & 28.5 & 11.6 & 23.5 & 35.1 & 9.4 & 24.2 & 33.6 \\
\hline Net absorption ${ }^{2}$ & 0 & 3.3 & 3.3 & 0 & 4.2 & 4.2 & 0 & 2.6 & 2.6 \\
\hline Absorption $\mathrm{NI} \rightarrow \mathrm{Cl}^{3}, \%$ & - & 16 & 10 & - & 15 & 11 & - & 10 & 7 \\
\hline Upper jejunum & & {$[\mathrm{n}=2]$} & & & {$[\mathrm{n}=1]$} & & & {$[\mathrm{n}=1]$} & \\
\hline $\mathrm{N}$ inflow & 11.1 & 17.4 & 28.5 & 11.6 & 23.5 & 35.1 & 9.4 & 24.2 & 33.6 \\
\hline $\mathrm{N}$ outflow & 14.7 & 11.4 & 26.1 & 11.5 & 21.0 & 32.5 & 13.1 & 16.7 & 29.8 \\
\hline Net absorption & -3.6 & 6.0 & 2.4 & 0.1 & 2.5 & 2.6 & -3.7 & 7.5 & 3.8 \\
\hline Absorption $\mathrm{C} 1 \rightarrow \mathrm{C} 2{ }^{3}, \%$ & -32 & 34 & 8 & 1 & 11 & 7. & -39 & 31 & 11 \\
\hline Lower jejunum & & {$[\mathrm{n}=2]$} & & & {$[\mathrm{n}=1]$} & & & {$[\mathrm{n}=1]$} & \\
\hline $\mathrm{N}$ inflow & 14.7 & 11.4 & 26.1 & 11.5 & 21.0 & 32.5 & 13.1 & 16.7 & 29.8 \\
\hline $\mathrm{N}$ outflow & 6.8 & 2.2 & 9.0 & 7.1 & 6.0 & 13.1 & 6.7 & 4.9 & 11.6 \\
\hline Net absorption & 7.9 & 9.2 & 17.1 & 4.4 & 15.0 & 19.4 & 6.4 & 11.8 & 18.2 \\
\hline Absorption $\mathrm{C} 2 \rightarrow \mathrm{C} 3^{3}, \%$ & 54 & 81 & 66 & 38 & 71 & 60 & 49 & 71 & 61 \\
\hline Terminal ileum & & {$[\mathrm{n}=3]$} & & & {$[\mathrm{n}=3]$} & & & {$[\mathrm{n}=3]$} & \\
\hline $\mathrm{N}$ inflow & 6.8 & 2.2 & 9.0 & 7.1 & 6.0 & 13.1 & 6.7 & 4.9 & 11.6 \\
\hline $\mathrm{N}$ outflow & 3.7 & 1.2 & 4.9 & 5.7 & 3.4 & 9.1 & 4.0 & 4.7 & 8.7 \\
\hline Net absorption & 3.1 & 1.0 & 4.1 & 1.4 & 2.6 & 4.0 & 2.7 & 0.2 & 2.9 \\
\hline Absorption $\mathrm{C} 3 \rightarrow \mathrm{C} 4{ }^{3}, \%$ & 46 & 45 & 46 & 20 & 43 & 31 & 40 & 4 & 25 \\
\hline Absorption $\mathrm{C} 1 / 2 \rightarrow \mathrm{C}^{4}, \%$ & 75 & - & 83 & 51 & - & 74 & 69 & - & 74 \\
\hline Digestibility $\mathrm{NI} \rightarrow \mathrm{C} 4^{5}, \%$ & - & 94 & 76 & - & 88 & 67 & - & 82 & 67 \\
\hline
\end{tabular}

${ }_{1}^{1}$ values represent means when number observations are $n \geq 2$

${ }^{2}$ calculated as $\mathrm{N}$ inflow $-\mathrm{N}$ outflow

${ }^{3}$ for each intestinal segment calculated as net absorption / $\mathrm{N}$ inflow $\mathrm{x} 100$

${ }^{4}$ absorption of endogenous $\mathrm{N}$ calculated as $\left(\mathrm{C} 1 / 2_{\mathrm{N} / \text { outflow }}-\mathrm{C} 4_{\mathrm{N} / \text { outflow }}\right) / \mathrm{C} 1 / 2_{\mathrm{N} / \text { outflow }} \times 100$; absorption of total $\mathrm{N}$ calculated as $\left(\mathrm{Cl}_{\mathrm{N} / \text { outflow }}-\mathrm{C} 4_{\mathrm{N} / \text { outflow }}\right) / \mathrm{Cl}_{\mathrm{N} / \text { outflow }} \times 100$

${ }^{5}$ digestibility of exogenous $\mathrm{N}$ (true) and of total $\mathrm{N}$ (apparent) was calculated as $\left(\mathrm{NI}-\mathrm{C} 4_{\mathrm{N} / \text { outflow }}\right)$ / NI $x 100$ 
the duodenal cannula. The endogenous $\mathrm{N}$ estimated in the upper jejunum digesta (C2) of pigs fed the SC and RC diets was 3.6-3.7 g/ kg DMI higher than in duodenal digesta. Pigs fed the $\mathrm{mSBM}$ diet had similar endogenous $\mathrm{N}$ flows between the duodenum and upper jejunum. The absorption of exogenous $\mathrm{N}$ was $31-34 \%$ in the upper jejunum of pigs fed on SC and RS diets, while it was only $11 \%$ for pigs on $\mathrm{mSBM}$ diet. The absorption of both endogenous and exogenous $\mathrm{N}$ in the lower jejunum $(\mathrm{C} 3)$ was higher for pigs fed the SC diet than for those fed the mSBM and RC diets. In the last segment of the small intestine (lower jejunum $\rightarrow$ terminal ileum) absorption of endogenous $\mathrm{N}$ was similar for the $\mathrm{SC}$ and $\mathrm{RC}$ diets $(40-46 \%$ of the inflow) and lower ( $20 \%$ of the inflow) for the $\mathrm{mSBM}$ diet. It was shown that the absorption of exogenous $\mathrm{N}$ was $43-46 \%$ of the inflow for the $\mathrm{SC}$ and $\mathrm{mSBM}$ diets while only $4 \%$ of the inflow for the RC diet.

Net absorption of total $\mathrm{N}$ in the small intestine (duodenum $\rightarrow$ terminal ileum), was 83,74 and $74 \%$ for the SC, mSBM and RC diet, respectively. Apparent ileal $\mathrm{N}$ digestibilities were 76,67 and $67 \%$, respectively. Total absorption of exogenous $\mathrm{N}$, which is equal to the true ileal $\mathrm{N}$ digestibility, was 94,88 and $82 \%$ for corresponding diets. The net reabsorption of endogenous $\mathrm{N}$ in the small intestine was $75 \%$ for the SC diet, $69 \%$ for the RC diet (in both diets estimated for the upper jejunum $\rightarrow$ ileum), and $51 \%$ for the mSBM diet (estimated for the duodenum $\rightarrow$ ileum).

\section{DISCUSSION}

\section{Duodenum}

The total $\mathrm{N}$ exceeded the $\mathrm{N}$ intake by $26-27 \%(6.8-7.4 \mathrm{~g} \mathrm{~N} / \mathrm{kg} \mathrm{DMI})$ in the duodenum of pigs fed the mSBM and RC diets and $38 \%(7.8 \mathrm{~g} \mathrm{~N} / \mathrm{kg}$ DMI) in those fed SC diet. Żebrowska et al. (1982, 1992) and Krawielitzki et al. (1996) reported that the amount of total $\mathrm{N}$ in the duodenum of pigs fed diets with various protein sources exceeded the intake by 12 to $20 \%(3.6-6.7 \mathrm{~g} \mathrm{~N} / \mathrm{kg} \mathrm{DMI})$. The higher amounts of total $\mathrm{N}$ in duodenum compared with $\mathrm{N}$ intake were caused by secretion of endogenous $\mathrm{N}$ from such sources as saliva, gastric juice, bile and pancreatic juice (Low and Żebrowska, 1989). In absolute values, assuming no reabsorption of endogenous $\mathrm{N}$ in the proximal gastro-intestinal tract (GIT), these sources may contribute to a total of about 6 to $13 \mathrm{~g}$ of $\mathrm{N} / \mathrm{d}$ up to the middle duodenum (Souffrant, 1991). In earlier studies with re-entrant cannulated pigs the flow of endogenous $\mathrm{N}$ in duodenal digesta, estimated as the difference between the total $\mathrm{N}$ passing duodenum and $\mathrm{N}$ intake, was about $7 \mathrm{~g} / \mathrm{d}$ in pigs fed the casein-based diet (Żebrowska and Buraczewska, 1972) to $14 \mathrm{~g} / \mathrm{d}$ in pigs fed soyabean meal-based diet (Buraczewska et al., 1975). 
In the present study, the use of diets with different protein sources did not influence markedly the flow of endogenous $\mathrm{N}$ in the duodenal digesta (range of 9.4 to $11.6 \mathrm{~g} \mathrm{~N} / \mathrm{kg} \mathrm{DMI}$ ). It seems, as far as pancreatic protein secretion is concerned, the different dietary $\mathrm{N}$ contents did not affect the amount of secreted endogenous $\mathrm{N}$ in pigs. These findings are in agreement with the data of Li et al. (1997).

Ten to $16 \%$ of the ingested $\mathrm{N}$ was already absorbed up to the middle duodenum. Krawielitzki et al. (1996) using the ${ }^{15} \mathrm{~N}$-isotope dilution technique for the labeling of endogenous $\mathrm{N}$, reported that $8.8 \mathrm{~g} \mathrm{~N} / \mathrm{kg}$ DMI of endogenous $\mathrm{N}$ was secreted and $14 \%$ of ingested $\mathrm{N}$ was absorbed in the proximal part of GIT in $30-\mathrm{kg}$ pigs fed wheat and meat-bone meal based diet. Also other studies suggest that part of exogenous $\mathrm{N}$ may already be absorbed in the stomach and the anterior duodenum (Żebrowska et al., 1983; Low and Żebrowska, 1989).

\section{Upper jejunum}

In the consecutive segments of the small intestine, the flow of both endogenous and exogenous $\mathrm{N}$ showed considerable variation among treatments. The flow of endogenous $\mathrm{N}$ in the upper jejunum tended to be higher than in the duodenum for the $\mathrm{SC}$ and $\mathrm{RC}$ diets, while it was as high as in the duodenum for the mSBM. Although the results for the $\mathrm{mSBM}$ and $\mathrm{RC}$ diets are based on one observation only, they support findings that the amount of endogenous $\mathrm{N}$ secreted in the intestinal juices of the upper segment of the small intestine exceeds, or at least equals, the $\mathrm{N}$ amount secreted up to the duodenum (Buraczewska, 1979; Simon and Żebrowska 1988; Souffrant, 1991). In this segment (duodenum $\rightarrow$ upper jejunum) intensive secretion of endogenous $\mathrm{N}$ and protein digestion occurs (Low and Żebrowska, 1989) while absorption is limited at this site (Buraczewska, 1981).

The tendency to lower absorption of exogenous $\mathrm{N}$ in pigs fed the mSBM diet, compared with the other two treatments, may be an effect of a lower protein digestion affected by a high TI activity.

\section{Lower jejunum}

The results of the $\mathrm{N}$ flow from the upper jejunum to the lower jejunum (middle part) are in agreement with findings of Buraczewska et al. (1975) and Buraczewska (1981) that this segment of the small intestine plays a dominant role in absorption of nitrogenous compounds. Among the tested diets, the highest absorption of exogenous $\mathrm{N}$ (about $80 \%$ ) was estimated for the SC diet that contained highly soluble dietary protein and low TIA. Also, the absorption of endogenous $\mathrm{N}$ was the highest for this diet. Nevertheless, the 70-percentage absorption of exogenous $\mathrm{N}$ estimated for the high TIA diet (mSBM), may suggest that there was sufficient enzyme activity for protein digestion in this part of the small intestine. According to Partridge et 
al. (1982), synthesis and secretion of protcolytic enzymes exceeds the amounts needed to digest dietary protein. Yen et al. (1977) and Żebrowska et al. (1985) showed that the use of raw soyabean, or soyabean TI, does not affect the activity of enzymes in pancreatic juicc. Schulze et al. (1993) reported a 30-50-percent (not significant) decrease in secretion of trypsin and chymotrypsin in pigs fed a diet with a high inclusion of purified soyabean TI. The absorption of endogenous $\mathrm{N}$ was the lowest in pigs fed the mSBM diet. Pigs fed the RC diet had similar endogenous $\mathrm{N}$ absorption to those fed the SC diet.

\section{Terminal jejunum and ileum}

In general, relative enrichments of $\mathrm{N}$ with ${ }^{15} \mathrm{~N}$ and the estimated amounts of both exogenous and endogenous $\mathrm{N}$ for the ileal digesta were within the range of values previously reported for the same feedstuffs (Grala et al., 1997a,b, unpublished data; Grala et al., 1998).

In pigs fed the $\mathrm{SC}$ and $\mathrm{mSBM}$ diets the percentage of absorption of exogenous $\mathrm{N}$ from the last part of the small intestine was similar, while pigs fed the RC diet had very low absorption in this segment of GIT. Previous results showed that the low digestibility of rapeseed protein is caused by very low digestibility of protein (only 26\%) in the hull fraction (Grala et al. 1997a, unpublished data; Grala et al., 1998). Moreover, most of the hull $\mathrm{N}$ is of non-protein origin and is strongly bound to the fibrous fraction. This $\mathrm{N}$ is hardly digested in the small intestine because digestive enzymes have restricted access to both the cell wall components and the enclosed cell contents. Additionally, rapeseed carbohydrates (hemicellulose, cellulose, pectin) and lignin may adsorb AA released during protein hydrolysis (Bell, 1984). As a result, more AA of both endogenous and exogenous origin pass into the large intestine.

In pigs fed the $\mathrm{mSBM}$ diet only $20 \%$ of endogenous $\mathrm{N}$ was absorbed in the last segment of the small intestine. Such low absorption may be associated with Tl that can form stable complexes with the pancreatic enzymes. In this way they are withdrawn from absorption (Liener and Kakade, 1980).

Total digestion and absorption of endogenous and exogenous nitrogen in the small intestine

The true and apparent ileal digestibilities of exogenous $\mathrm{N}$ of the dicts, with the exception of the SC diet, were within the range of previously reported values for the same feedstuffs (Grala et al., 1997a,b, unpublished data; Grala et al., 1998).

Net absorption of total $\mathrm{N}$ at the terminal ileum was 83,74 and $74 \%$ of intake for the SC, mSBM and RC diets, respectively. The net reabsorption of endogenous $\mathrm{N}$ was estimated as 75,51 and $69 \%$ for the corresponding diets. The value estimated 
for the SC diet is very close to the results (70-79\%) reported by other authors for highly digestible protein sources with low levels of ANF (Souffrant et al., 1986, 1993; Żebrowska ct al., 1992; Krawielitzki et al., 1996). Since the other two values from the present study are below the range given above, this may indicate a specific effect of protein sources on the reabsorption rate of endogenous $\mathrm{N}$ in the small intestine.

The results of the present study suggest that soyabean concentrate, a mixture of toasted and untoasted soyabean meal, and rapeseed cake cause a different reabsorption of endogenous $\mathrm{N}$ up to the end of the small intestine.

\section{CONCLUSIONS}

Regardless of the dietary protein source fed to pigs, the middle segment of the small intestine is the most intense site of endogenous and exogenous $\mathrm{N}$ absorption in the pig. The flow of both endogenous and exogenous nitrogen along the small intestine depended on the protein source. It seems that reabsorption rather than secretion of endogenous nitrogen along the small intestine of the pig is influenced by different dietary factors.

\section{ACKNOWLEDGEMENTS}

The authors would like to thank P. van Leeuwen, D. van Kleef and K. Deuring from the TNO-Department of Animal Nutrition and Physiology (ILOB), Wageningen, The Netherlands, for excellent technical advices and training of the surgical team from The Kielanowski Institute of Animal Physiology and Nutrition, Jabłonna, Poland.

\section{REFERENCES}

AOAC, 1984. Official Methods of Analysis, 14th Edition. Association of Official Analytical Chemists, Arlington, VA

ARC, 1981. Agricultural Research Council. The Nutrient Requirements of Pigs. Slough: Commonwealth Agricultural Bureaux, Farnaham, U.K.

Bell J.M., 1984. Nutrients and toxicants in rapeseed meal: a review. J. Anim. Sci. 58, 996-1010

Buraczewska L., 1979. Secretion of nitrogenous compounds in the small intestine of pigs. Acta Physiol. pol. 30. 321-328

Buraczewska L., 1981. Absorption of amino acids in different parts of the small intestine in growing pigs. Acta Physiol. pol. 32, 419-428

Buraczewska L., Buraczewski, S., Żebrowska, T., 1975. Digestion and absorption in the small intestine of pigs. 2. Amino acid content in digesta and their absorption. Rocz. Nauk rol. B-97, 103-I15 
CVB, 1994. Centraal Veevoederbureau. Veevoedertabel. PO Box 1076, 8200 BB Lelystad (The Netherlands)

De Lange C.F.M., Mohn S., Nyachoti C.M., 1995. Partitioning of protein and energy intake in grower-finisher pigs. In: M. Ivan (Editor). Animal science and development: moving towards a new century. Symposium on Determination of Production Efficiency in Swine. Ottawa, Ontario (Canada), pp. 339-360

EEC (European Economic Community), 1990. Standard Method for Analysis of Glucosinolates. Method Nr. 1864/90. EEC Publications, July 3, 1990, Nr. L 170/27, Brussels (Belgium)

Grala W., Verstegen M.W.A., Jansman A.J.M., Huisman J., van Leeuwen P., 1997a. Apparent protein digestibility and recovery of endogenous nitrogen at the terminal ileum of pigs fed diets containing various soyabean products, peas or rapeseed hulls. Anim. Feed Sci. Technol. (accepted)

Grala W., Verstegen M.W.A., Jansman A.J.M., Huisman J., van Leeuwen P., Tamminga S., 1997b. Effects of ileal endogenous nitrogen losses and of dietary amino acid supplementation on nitrogen retention in growing pigs. Anim. Feed Sci. Technol. (accepted)

Grala W., Verstegen M.W.A., Jansman A.J.M., Huisman J., van Leeuwen P., 1998. Ileal apparent protein and amino acid digestibilities and endogenous nitrogen losses in pigs fed soyabean and rapeseed products. J. Anim. Sci. 76 (in press)

Huisman J., Verstegen M.W.A., van Leeuwen P., Tamminga S., 1993. Reduction of N pollution by decrease of the excretion of endogenous $\mathrm{N}$ in pigs. In: M.W.A. Verstegen, L.A. den Hartog, G.J.M van Kempen, J.H.M. Metz (Editors). Nitrogen flow in pig production and environmental consequences. EAAP Publication, No. 69. Pudoc, Wageningen (The Netherlands), pp. 55-61

Kimura F.T., Miller V.L., 1957. Improved determination of chromic oxide in cow feed and faeces. Agr. Food Chem. 5, 216

Krawielitzki K., Żebrowska T., Kreienbring F., Schadereit R., Kowalczyk J., 1996. Absorption and secretion of exogenous and endogenous $\mathrm{N}$ along the digestive tract and kinetic parameters of protein metabolism in growing pig. 1. Estimation by digesta exchange between ${ }^{15} \mathrm{~N}$-labelled and unlabelled pigs. J. Anim. Physiol. Anim. Nutr. 76, 46-56

Li S., Sauer W.C., Huang S.X., Gabert V.M., 1997. Exocrine pancreatic secretions in growing pigs fed diets containing different levels of protein from soyabean meal. J. Anim. Feed Sci. 6 , 207-217

Liener I.E., Kakade M.L., 1980. Protease inhibitors. In: I.E. Liener (Editor). Toxic constituents of plant foodstuffs. Academic Press. New York, pp. 7-71

Low A.G., Żebrowska T., 1989. Digestion in pigs. In: H.D. Bock, B.O.Eggum, AG. Low, O.Simon, T.Żebrowska (Editors). Protein metabolism in farm animals. Oxford, UK, VEB Deutscher Landwirtschaftsverlag, Berlin, pp. 53

Nyachoti C.M., De Lange C.F.M., McBride B.W., Schulze H., 1997. Significance of endogenous gut protein losses in the nutrition of growing pigs: a review. Can. J. Anim. Sci. 77, 149-163

Partridge I.G., Low A.G., Sambrook 1.E., Corring T., 1982. The influence of diet on the exocrine pancreatic secretion of growing pigs. Brit. J. Nutr. 48, 137-145

Philips Scientific. 1988. Philips Scientific Atomic Absorption Date Book. Philips Scientific, Holland

Schulze H., Huisman J., Verstegen M.W.A., van Leeuwen P., 1993. Physiological effects of isolated soya trypsin inhibitor (sTI) on pigs. In: A.F.B. van der Poel, J. Huisman, H.S. Saini (Editors). Recent advances of research in antinutritional factors in legume seeds. Proceedings of the 2nd International Workshop, Wageningen, EAAP Publication No. 70. Wageningen Press (The Netherlands), pp. 191-194 
Schulze, H., Van Leeuwen P., Verstegen M.W.A., van den Berg J.W.O., 1995. Dietary level and source of neutral detergent fiber and ileal endogenous nitrogen flow in pigs. J. Anim. Sci. 73, $441-448$

Simon O., Żebrowska T., 1988. Secretion of nitrogenous compounds into the lumen of the digestive tract. In: L. Buraczewska, S. Buraczewski, B. Pastuszewska, T. Żebrowska (Editors). Digestive physiology in the pig. Proceedings of the 4th International Seminar. Institute of Animal Physiology and Nutrition, Polish Academy of Sciences, Jabłonna (Poland), pp. 59-69

Souffrant W.B., 1991. Endogenous nitrogen losses during digestion in pigs. In: M.W.A. Verstegen, J. Huisman, L.A. den Hartog (Editors). Digestive physiology in pigs. EAAP Publication No. 54. Pudoc, Wageningen (The Netherlands), pp. 147-166

Souffrant W.B., Darcy-Vrillon B., Corring T., Laplace J.P., Köhler R., Gebhardt G., Rérat A., 1986. Recycling of endogenous nitrogen in the pig: Preliminary results of a collaborative study. Arch. Anim. Nutr. 36, 269-274

Souffrant W.B., Rérat A., Laplace J.P., Darcy-Vrillon B., Köhler R., Corring T., Gebhardt G., 1993. Exogenous and endogenous contributions to nitrogen fluxes in the digestive tract of pigs fed a casein diet. III. Recycling of endogenous nitrogen. Reprod. Nutr. Develop. 33, 373-382

Van Leeuwen P., Van Kleef D.J., van Kempen G.J.M., Huisman J., Verstegen M.W.A., 1991. The Post-Valve-T-Caecum cannulation technique in pigs applicated to determine the digestibility of amino acid in maize, groundnut and sunflower meal. J. Anim. Physiol. Anim. Nutr. 65, 183-193.

Van Oort M. G., Hamer R. J., Slager E.A., 1989. The trypsin inhibitor assay: improvement of an existing method. In: J. Huisman, A.F.B. van der Poel, I.E. Liener (Editors). Recent advances of research in antinutritional factors in legume seeds. Pudoc, Wageningen (The Netherlands), pp. $110-113$

Van Soest P.J., 1973. Collaborative study of acid detergent fibre and lignin. J. Assoc. Off. Agric. Chem. 56, 513-530

Yen J.T., Jensen A.H., Simon J., 1977. Effect of dietary raw soyabean and trypsin inhibitor on trypsin and chymotrypsin activities in the pancreas and in small intestinal juice of growing swine. J. Nutr. 107, 156-165

Żebrowska T., Buraczewska L., 1972. Influence of dietary protein level on the rate of digestion in the small intestine of pigs. I. Amount and composition of digesta. Rocz. Nauk rol. B-94, 81-96 (in Polish)

Żebrowska T. Kowalczyk J., Krawielitzki K., Hennig U., Schadereit R., 1992. Studies on absorption and secretion of ${ }^{16} \mathrm{~N}$ endogenous nitrogen along the digestive tract of pigs. J. Anim. Feed Sci. 1, 151-163

Żebrowska T., Low A.G., Żebrowska H., 1983. Studies on gastric digestion of protein and carbohydrates, gastric secretion and exocrine pancreatic secretion in the growing pig. Brit. J. Nutr. 49 , $401-410$

Żebrowska T., Simon O., Münchmeyer R., Wolf E., Bergner H., Żcbrowska H., 1982. Flow of endogenous and exogenous amino acids along the gut of pigs. Arch. Anim. Nutr. 32, 431-444

Żebrowska T., Tanksley T.D. Jr., Knabe, D.A., 1985. The influence of differently processed soyabean meals on the exocrine pancreatic secretion of growing pigs. In: A. Just, H. Jørgensen, J.A. Fernández (Editors). Digestive physiology in the pig. Proccedings of the 3 rd International Seminar. Beretning Statenshusdyrbrugsfors $\varnothing g$ No. 580, Copenhagen (Denmark), pp. 149-151 


\section{STRESZCZENIE}

\section{Przepływ endogennego i egzogennego azotu w różnych odcinkach jelita cienkiego u świń, karmionych paszami zawierającymi koncentrat sojowy, śrutę sojową lub wytlok rzepakowy}

W doświadczeniu użyto 6 wieprıków o początkowej masie ciała $27,5 \pm 1,2 \mathrm{~kg}$. Każde zwierzę zaopatrzono w 2 kaniule umieszczone $w$ różnych częściach jelita cienkiego. Założono łącznie 12 kaniul, z czego $3 \mathrm{w}$ dwunastnicy (C1), 3 w początkowej części jelita czczego (C2), 3 w końcowej części jelita czczego (C3) oraz 3 przy końcu jelita biodrowego (C4). Rozmieszczenie par kaniul pozwalało na zbadanic przeplywu oraz wchłaniania $\mathrm{N}$ endogennego (Ed-N) i egzogennego (Ex-N) w poszczególnych odcinkach jelita cienkiego. Zwierzęta miały założone katetery do żyły szyjnej zewnętrznej celem pobierania próbek krwi i do tętnicy szyjnej wspólnej użytej do ciagłej infuzji ${ }^{15} \mathrm{~N}$-leucyny (4.2 mg/kg ${ }^{1.75} /$ dobę). Doświadczenie przeprowadzono w układzie przemiennym w 3 okresach po $12 \mathrm{dni}$; w ostatnich 72 god7. każdego okresu pobierano treść pokarmową i próbki krwi. Diety doświadczalne zawierały: koncentrat sojowy (SC), mieszankę tostowanej i nietostowanej poekstrakcyjnej śruty sojowej (mSBM) z dużą zawartością inhibitora trypsyny, wytlok rzepakowy (RC) z dużą zawartością NDF oraz skrobię kukurydzianą i dodatki witaminowo-mineralne.

W treści pokarmowej dwunastnicy świń (C1) karmionych dietami SC, mSBM i RC, N ogólny stanowił odpowiednio 138,127 i 126\% N pobranego; w odcinku przed kaniulą $\mathrm{Cl}$ zostało wchłonięte 16,15, i $10 \% \mathrm{~N}$ pobranego, natomiast wydzielanie wynosiło odpowiednio $11,1,11,6$ i $9,4 \mathrm{~g} \mathrm{Ed}-\mathrm{N}, \mathrm{w}$ przeliczeniu na kg pobranej suchej masy paszy. Dla wyżej wymienionych diet, w treści pokarmowej $z$ kaniuli $\mathrm{C} 2, \mathrm{~N}$ ogólny wynosił odpowiednio $126,117 \mathrm{i} 111 \% \mathrm{~N}$ pobranego, uległo wchłonięciu 34 , 11 i $31 \%$ Ex-N przepływającego przez kaniulę $\mathrm{C} 1$ oraz nastąpiło dalsze zwiększenie puli Ed-N przy żywieniu dietami SC i RC. W treści pokarmowej końcowej części jelita czczego (C3), $\mathrm{N}$ ogólny stanowił odpowiednio $44,47 \mathrm{i} 43 \% \mathrm{~N}$ pobranego. W porównaniu z przepływem $\mathrm{N} w \mathrm{C} 2$, w dalszej części jelita czczego uległo wchłonięciu 81,71 i 71\% Ex-N oraz 54, 38 i 49\% Ed-N, odpowiednio przy żywieniu dietami SC, mSBM i RC. Przy koncu jelita cienkiego (C4), przepływ N ogólnego stanowił odpowiednio 24,33 i 33\% N pobranego, a strawność rzeczywista wynosila 94, 88 i $82 \%$. Stopień wchłaniania zwrotnego Ed-N w jelicie cienkim oszacowano na 75,51 i $69 \%$, przy żywieniu odpowiednio SC, mSBM i RC.

Stwierdzono, że niezależnie od źródła białka w diecie, środkowa część jelita cienkiego jesı miejscem największego wchłaniania Ed-N i Ex-N. Wydaje się, że w jelicie cienkim u świni czynniki żywieniowe (inhibitor trypsyny, włókno) mogą wpływać bardziej na wchłanianie zwrotne Ed-N niż na jego wydzielanie. 